\title{
THE CONCEPTUAL APPROACH TO THE DEVELOPMENT OF METHODOLOGIES FOR THE ASSESSMENT OF SECURITY ENVIRONMENT
}

Identifying the issue and its relevance. The article is dedicated to the general issues of ensuring the National Security of the State, in particular, the promising development areas of the Defence and Security Sector of Ukraine. The current legislative acts and regulations in the field of national security (The Decree of the President of Ukraine, 2015: No. 555/2015; The Decree of the President of Ukraine, 2015: No. 287/2015; The Decree of the President of Ukraine, 2016: No. 92/2016; The Law of Ukraine, 2018: No. 2469-VIII) ,define the tasks aimed at ensuring national security in its most significant areas based on the assessment of the security environment, financial and economic opportunities of the State, carried out within the framework of an integrated review of the security and defence sector of Ukraine. However, modern Ukraine has not yet developed the methodological toolkit necessary to assess the security environment. Moreover, the very concept of "security environment" is not defined, which makes the resources for the defence and securityrelated research hard to find. Everything mentioned above determines the relevance of this publication.

Analysing recent research papers and publications. According to Article 28, paragraph 2 of the Law of Ukraine on National Security, "the Ukraine's Military Security Strategy defines ways of achieving the goals and implementing the State policy priorities in the military field, defence and military capability development, in particular:

- the security environment (global, regional and national aspects) in the context of military security;

- state policy goals, priorities and tasks in the military field, defence and the development of military capabilities;

- socio-political, economic and other conditions for the state policy in the military field, defence and the development of military capabilities implementation, including military-political and military-strategic constraints;

- solutions to achieve the state policy goals in the military field, defence and the development of military capabilities;

- providing resource support for the defence needs; 
- the advanced defence management model, the Armed Forces of Ukraine and other components of the defence forces in relation to certain State defence tasks, strategy and criteria for achieving common defence capabilities;

- possible scenario for the security forces and the defence forces application to fulfil the state defence tasks. The security and defence sector responsibilities distribution to manage Ukrainian defence, to protect its sovereignty, territorial integrity and inviolability;

- risks management in the field of military security."

However, the law does not define the notion of security environment itself.It introduces the elements of strategic uncertainty and subjectivity to the Strategy of Military Security.

Article 5 of the Military Doctrine of Ukraine points out that "the security environment around Ukraine is complex and dynamic. Global military-political instability has resulted in the armed conflict in the East of Ukraine, the military-political instability in the Middle East, the global struggle for influence on world financial and energy flows. Leading states are increasing the budget of military spending, fostering the development of new weapons, boosting the intensity of military exercises." Article 6 mentions the main tendencies that affect the formation and development of a security environment in the world, although there are no references to the methodical apparatus, literary and legislative sources that provided the foundation for such conclusions. The world security environment tailoring and development is declared "to be under the influence of the following main trends:

- increasing the contradictions in the spheres of influence division between the world forces, increasing their aggressiveness, unyieldingness, the desire to benefit from breaking military-strategic balance, particularly the conflict escalation between the United States and the Russian Federation;

- conflict escalation in the Middle East and North Africa, an increase in the religious extremism and the spread of radical Islam in the Central Asia, the conflict over the islands involving Asia-Pacific regions;

- current crisis and ambiguity in the new international security policy, the weakening role of international security institutions, attempts to strengthen the role of military force outside the existing mechanisms of international security;

- there has been a focus shift in military conflicts to the asymmetrical army force application involving 'illegal armed formations,' as well as comprehensive use of military and non-military War instruments (economic, political, informational and psychological, etc.), Therefore it has fundamentally changed the nature of War theatre;

- the UN Charter, the Final Act of the 1975 Meeting on Security and Cooperation in Europe and other international treaties norms and principles violation;

- weakening legal restrictions on the military force usage by the states outside their borders;

- global climate change, reduction of natural resources, drinking water shortages, food products, increased migration processes, as well as increased risks of largescale emergencies of natural and man-caused nature;

- expanding the scope of terrorism, piracy, and other phenomena related to the armed violence abuse," but there is no guidance on its practical application. 
Chapter II titled Security Environment Assessment of the Concept for the Development of the Security and Defence Sector of Ukraine only lists the existing threats, it does not, however, provide any information on the identification process or the authenticity of the identified threats, priorities, and a kind of response necessary (immediate, short-term, long-term; symmetric or asymmetric).

Evaluating the security environment other researches (Bohdanovych, Pavlovskyi, 2017: 10-11) focus on the assessment of the military-political or military-strategic situation, which prevents them from identifying security environment information on the destructive processes, phenomena, risks, and threats, as well as the conditions necessary for the implementation of national interests.

The aim of the article is to design conceptual approaches to the development of a generalized methodology for the security environment evaluation.

Writing the body based on core research data. In order to effectively implement the national interests of the state in the modern security environment, it is indispensable to be ready to identify current threats and risks, to assess their nature, level, and scale, and to predict its dynamics and the damage in the predominant national security areas in case they are ever to take place. In addition, it is of utmost importance to track global and local activities, the leading nations' strategic polices, trends and tendencies of the situation development in selected regions and the world. To address these issues, a comprehensive monitoring of threats and dangers is arranged and carried out within the framework of ensuring National Security. The monitoring of threats and risks is defined as a permanent, deliberate, systematic supervision aimed at identifying phenomena and factors that impede or prohibit the implementation of national interests in particular areas of the State National Security researches (Bohdanovych, Svyda, Skulish, 2012: vol. 1, 400). Monitoring of threats is conducted in the security environment comprised of geopolitical, political, diplomatic, military, economic, informational and other fields in which favourable conditions or dangerous phenomena are emerging, exist, are accumulated or are manifested, as well as potential and current threats to national interests. All this creates the conditions under which the State implements its national security policy, interacts with international security structures, strategic partners, allies, militarypolitical and other bodies and organizations to ensure its sustainable development within certain timeframe.

Data monitoring proves to be insufficient in ensuring effective implementation of national interests. Therefore, it is necessary to develop a more professional approach to processing and analysing the security environment data which is not being documented over the course of monitoring. The data processing requires higher level of professional training for analysts and appropriate methodological tools. Security environment evaluation methodology, shown in Fig. 1, may become the crucial component of the methodological toolkit.

The methodology can consist of 14 main blocks, which carry out analytical, logical, expert, comparative and other procedures with the information received from the security environment in relation to the destructive processes, phenomena, risks and threats, as well as conditions needed for the implementation of national interests.

The given methodology is eligible to be expanded and supplemented by the other procedures depending on the tasks for the researchers to be solved. 
Fig. 1. Generalized scheme of the methodology for evaluating the security environment

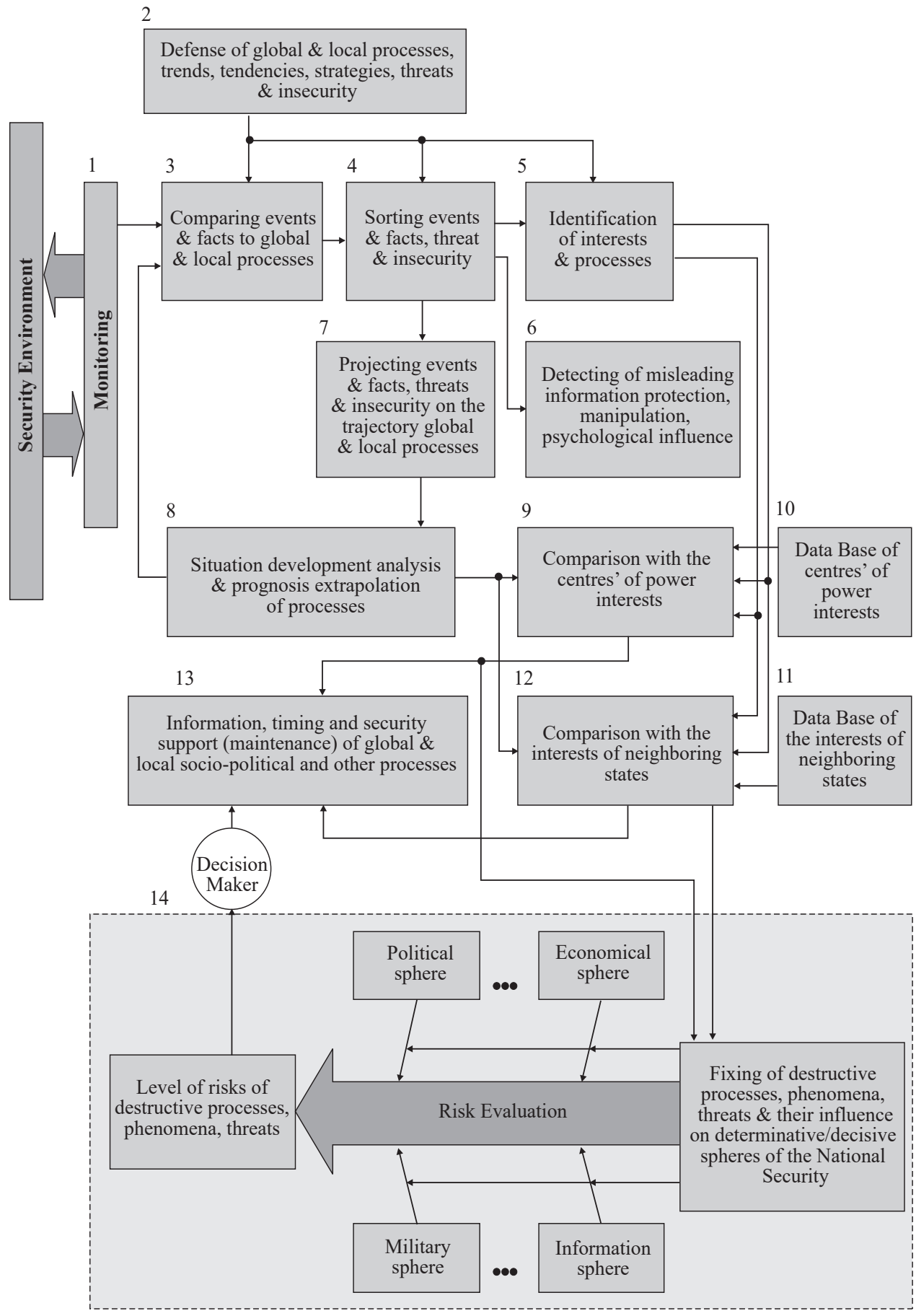


Block 1 deals with the monitoring carried out in accordance with the methodology described in (Bohdanovych, Svyda, Skulish, 2012: Vol. 4, 407; Bohdanovych, Svyda, Skulish, 2012: Vol. 1, 95). The destructive phenomena, factors, risks and threats of military and hybrid nature are detected. Their scale and the nature of impact on the military security of the State and the vital areas of national security are preliminarily evaluated. The revealed destructive phenomena, factors, dangers and military, hybrid and other threats are added to the corresponding databases. If appropriate, identified perils fall into groups that require immediate, medium and long-term responses.

Block 2 collects information about global and local processes in international relations, the states generating these processes, current trends and tendencies, risks, potential and actual threats to the military security, strategies of the centres of power and neighbouring states, Its possible negative impact on the state national security is to be investigated etc.

Block 3 deals with the data, obtained during the monitoring, which is compared to the data contained in the data base (Block 2) in order to, at least approximately, classify them as certain global and local processes, or to identify new phenomena that affect the implementation of national interests. New phenomena, threats and processes should be recorded in the relevant partitioned databases.

Block 4 conducts a more in-depth segregation of the events, facts, risks and threats received during the monitoring phase. The proposals to elaborate for their distribution according to the urgency are developed (urgent, mid-term, future considerations).

Block 5 provides the identification of separate facts, events and phenomena with global and local processes, risks, threats and actions of other states (Bohdanovych, Svyda, Skulish, 2012: Vol. 1, 101). Depending on the conventional state procedures for processing classified and public data, such data can be consolidated in Block 5 or restricted, for example, from intelligence structures.

Block 6 completes the segregations of the information from Block 4; revealing the facts of misinformation, manipulation, psychological effects, informational cover-ups of the promotion of certain interests through the information space; guidance for agents of influence on the establishment of a certain public opinion, oppositional counteraction, etc. As a rule, appropriate national information technologies are used to solve these problems.

Block 7. The information from Block 4 is projected on the causes of global and local processes. In particular, it is detected which processes are becoming more intense and which processes Ukraine is to be involved in based on the desires of the interested states, etc. The experts in this field and analysts solve these tasks with the specially developed mathematical support applied.

Block 8 is based on the information obtained from Block 7 and analyses the identified threats, evaluates their dynamics, forecasts the military-political and international situation; extrapolates the global and local processes in the short and mid-term perspectives; develops and evaluates the most "serious" scenarios for the State, primarily for the short-term perspective. The proposals on the first-stage, both direct and asymmetrical, responses to the military and other threats are developed.

Block 9. The logical comparison of the information received in Block 8 with the interests of the centres of power, which, for convenience, are placed in the database 
(Block 10), is carried out. Simultaneously, the information from Block 8 is submitted to Block 12 for comparison with the interests of neighbouring states (Block 11). Such "binding" of the detected destructive factors (threats) allows them to be structured according to the scale and priority, and, respectively, to organize information, timing and security monitoring (Bohdanovych, Svyda, Vysidalko, 2013: 10). of global, local and other processes, that are initiated by centres of power, neighbouring States or their coalitions in Block 13.

Block 14. The detected destructive processes, factors, separate facts, which were grouped in Blocks 9 and 12, by their affiliation (proximity) to the interests of the centres of power and interests of neighbouring states or coalitions of States, are being analysed concerning the power of their influence on the defining areas of national security. The appropriate risks of the implementation of threats and socio-political instability of the State, the reduction of the level of military security of the State and other destructive consequences for national security are being evaluated. The information, received in Block 14, can be used by the Decision Making person (institution) in the field of national security for adjusting the parameters of information, timing and security monitoring of global, local and other processes described in Block 3.

It is certain that the efficient evaluation of the security environment requires the involvement of high level analysts in this process. Unfortunately, it is not a primary task for the state. In addition, the experts, who may be involved in certain stages of the methodology, should be trained in such disciplines as the foundations of geopolitics and the foundations of national security, which, at different times, were taught at the departments of national security prior to their restructuring at the National Academy of Public Administration under the President of Ukraine. The second decisive factor for the successful implementation of this methodology is defined by the development of an applicable information technology for supporting managerial decisions as a component of the information and analytical support of the Main Situational Centre of Ukraine (The Decree of the President of Ukraine, 2015: No. 287/2015).

Nowadays, the most difficult task is to justify the necessary military and non-military (hybrid) forces and means with the available resources for the detected military threats de-escalation.

It proves the necessity to develop a specific scientific and methodical apparatus for security assistance and implementation of national interests in the field of security and defence.

The Ukrainian research findings in methodological apparatus show that the main method is generating ideas (the method of brainstorming) and an expert evaluation (forecasting) method. Taking into account the specific conditions for ensuring military security in Ukraine, its military and non-military capabilities, the security support fundamentals, the integrated potential technique can be developed to counteract military threats. The method development is currently hampered by the methodical apparatus for evaluating the security environment being worked out. Therefore, the proposed method reveals new prospects for the integrated use of military and non-military forces and means. It will ultimately allow us to spend resources more reasonably from economical point of view to ensure national and military security of the state. 
Conclusion. Suggested conceptual approach enables an opportunity for the development of a cohesive methodology for security environment evaluation that can be implemented in the functioning of the Main Situational Centre of Ukraine. In subsequent publications, it is planned to specify the separate stages and formulate the source data for the development of the information technology that would provide automation of the security environment evaluation process.

\title{
REFERENCES
}

Bohdanovych V. Yu., Svyda I. Yu., Skulish Ye. D. (2012), Theoretical and methodological bases of ensuring national security of Ukraine, Vol. 1: Theoretical foundations, methods and technologies of ensuring national security of Ukraine, National Academy of the Security Service of Ukraine, Kyiv, 548 p.

Bohdanovych V. Yu., Svyda I. Yu., Skulish Ye. D. (2012), Theoretical and methodological bases of ensuring the national security of Ukraine, Vol. 4: Military security of Ukraine and ways of its provision, National Academy of the Security Service of Ukraine, Kyiv, $400 \mathrm{p}$.

Bohdanovych V. Yu., Svyda I. Yu., Vysidalko A. L (2013), Analysis of possibilities the system of providing of Ukraine national safety in relation to comprehensive support of realization safety accompaniment of national interests, "Science and Technology of Air Forces of the Armed Forces of Ukraine", No. 3 (12), pp. 5-12, https://doi.org/10.30748/nitps.2013.12.01.

Bohdanovych V.Yu., Pavlovskyi O. V.(2017), Integrated model of management of integrated potential of counteraction to military-level threats to provide a certain level of military security of the state, „Science and Technology of Air Forces of the Armed Forces of Ukraine”, No. 1 (26), pp. 6-11, https://doi.org/10.30748/nitps.2017.26.01.

The Decree of the President of Ukraine "On the Strategy of the National Security of Ukraine" (2015), No. 287/2015.

The Decree of the President of Ukraine „On the new edition of the Military Doctrine of Ukraine” (2015), No. 555/2015.

The Decree of the President of Ukraine „On the Concept of Development of the Security and Defense Sector of Ukraine" (2016), No. 92/2016.

The Law of Ukraine „On the National Security of Ukraine” (2018), No. 2469-VIII.

\begin{abstract}
The main conceptual approaches to the development of a security environment evaluation methodology that would provide more skilled processing of information circulating in a security environment but not fixed during monitoring are considered. The method contains 14 main blocks, which carry analytical, logical, expert comparative and other procedures with the information received from the security environment in relation to destructive processes, phenomena, dangers, threats, as well as conditions in which the implementation of national interests takes place. The novelty of the procedures introduced is a comparison of facts, events detected during monitoring of global and local processes, sorting of events, facts, dangers, threats, etc., on the basis of which identification of geopolitical and other interests of other states is carried out, detection of misinformation, information coverage of various kinds of manipulations and psychological effects. The procedure of projecting events, facts, dangers, threats on the trajectory of global
\end{abstract}


and local processes allows predicting the dynamics of global and local processes, providing information-time and security support for global and local processes, and assessing the risks of detected destructive phenomena and processes allows timely adjusting the parameters of the information - time and security support of global, local and other processes and make managerial decisions in the system of providing the national and military security more reasonably.

Keywords: security environment, geopolitical interests, national interests, national security, threats, global processes, local processes, risk, identification of processes

\section{PODEJŚCIE KONCEPCYJNE DO ROZWOJU METODOLOGII OCENY ŚRODOWISKA BEZPIECZEŃSTWA}

\section{STRESZCZENIE}

Artykuł omawia główne koncepcyjne podejścia do opracowania metodologii oceny środowiska bezpieczeństwa, która zapewniłaby sprawniejsze przetwarzanie informacji krążących w środowisku bezpieczeństwa, ale nie pochodzących z monitoringu. Metoda obejmuje 14 głównych bloków, w ramach których procedury analityczne i logiczne, porównania eksperckie i inne przeprowadzane są na informacjach otrzymanych ze środowiska bezpieczeństwa w odniesieniu do procesów destrukcyjnych, zjawisk, niebezpieczeństw, zagrożeń, a także warunków realizacji interesów narodowych. Nowością wprowadzonych procedur jest porównanie faktów i zdarzeń wykrytych podczas monitorowania procesów globalnych i lokalnych, klasyfikacja zdarzeń, faktów, niebezpieczeństw, zagrożeń itp., na podstawie których określane są interesy geopolityczne i inne państw, identyfikuje się dezinformację oraz informacje przekazywane na temat różnego rodzaju manipulacji i skutków psychologicznych. Procedura prognozowania zdarzeń, faktów, niebezpieczeństw i zagrożeń na trajektorii procesów globalnych i lokalnych pozwala przewidywać dynamikę tych procesów, zapewnia szybko dostępną informację i wspieranie ich bezpieczeństwa, oraz ocenę ryzyka wykrytych zjawisk destrukcyjnych, co pozwala na sprawne dostosowywanie parametrów czasu informacji i wsparcie bezpieczeństwa oraz podejmowanie decyzji w systemie zapewniania bezpieczeństwa narodowego i wojskowego w sposób bardziej racjonalny.

Słowa kluczowe: środowisko bezpieczeństwa, interesy geopolityczne, interesy narodowe, bezpieczeństwo narodowe, zagrożenia, procesy globalne, procesy lokalne, ryzyko, identyfikacja procesów 